DOI

\title{
ВИДИ ОРГАНІЗАЦІЇ САМОСТІЙНОЇ РОБОТИ СТУДЕНТІВ 3 ВНУТРІШНЬОЇ МЕДИЦИНИ
}

\author{
Р. В. Деніна
}

\author{
ДВНЗ “Івано-Франківський національний медичний університет”
}

\section{TYPES OF INDEPENDENT WORK OF STUDENTS OF INTERNAL MEDICINE}

\section{SHEI "Ivano-Frankivsk National Medical University"}

R. V. Denina

\begin{abstract}
У даній статті обговорюються форми організації самостійної роботи студентів 5 курсу на кафедрі внутрішньої медицини № 2 та медсестринства ДВНЗ “Івано-Франківський національний медичний університет”. Основними формами організації самостійної роботи студентів 5 курсу з внутрішньої медицини є навчальна історія хвороби, робочий зошит і тестові завдання для контролю отриманих теоретичних знань.
\end{abstract}

This article discusses the forms of independent work of 5 th course students at the Department of Internal Medicine № 2 and Nursing of SHEI “Ivano-Frankivsk National Medical University”. The main forms of independent work of 5th course students of Internal Medicine are an educational medical history, workbooks and test tasks for monitoring theoretical knowledges.

Вступ. Самостійна робота студентів є важливою ланкою навчального процесу і виконується під методичним керівництвом викладача, але без його безпосередньої участі [2]. Самостійна робота студентів $€$ важливим компонентом навчального процесу при вивченні внутрішньої медицини студентами 5 курсу на кафедрі внутрішньої медицини № 2 та медсестринства. У ході виконання самостійної роботи студентами відбувається узагальнення, систематизація отриманих теоретичних знань, закріплення практичних навичок. Цей вид навчальної діяльності навчає студентів самостійності, що $€$ необхідним у будь-якій професійній діяльності, виробляє здатність самостійно приймати відповідальні рішення, знаходити оптимальний вихід зі складних ситуацій, сприяє формуванню мотивації до навчання [3]. Вона формує самостійність як важливу рису характеру, що займає провідне місце в структурі особистості сучасного фахівця. Самостійна робота дозволяє знизити аудиторне навантаження як на студента, так і на викладача.

У вищому навчальному закладі за формою подання результатів $€$ такі види самостійної роботи студентів: усна - доповідь, повідомлення, коментар, презентація ситуації; письмова - опорні конспекти, таблиці, схеми, термінологічні словники, рефера-

(c) Р. В. Деніна ти, контрольні роботи, курсові та дипломні роботи; конструкторська - моделі, макети, наочність; інтерактивна - навчальне спілкування на форум-сторінці в гіпермедійному середовищі.

Основна частина. Основними формами організації самостійної роботи студентів 5 курсу на кафедрі внутрішньої медицини № 2 та медсестринства $€$ навчальна історія хвороби, робочий зошит, реферат та тематичні завдання 3 подальшим підсумковим тестовим контролем отриманих знань.

Основними принципами відбору матеріалу для самостійного вивчення $є$ наступні: зведення до мінімуму обсягу і складності матеріалу, відведеного для самостійного вивчення студентами з метою відповідності обсягу та рівня складності матеріалу можливостям кожного студента і часового інтервалу, відведеного для засвоєння матеріалу; узгодженість навчальних матеріалів (аудиторної та позааудиторної роботи); дотримання єдиних дидактичних вимог самопідготовки, контролю та оцінки знань і навичок.

Історія хвороби з внутрішньої медицини є варіантом навчально-дослідної роботи студентів і дозволяє закріпити отримані теоретичні знання та практичні навички.

Особливістю історії хвороби є те, що вона оформляється як історія хвороби хворого, що знаходиться 
на стаціонарному лікуванні в Івано-Франківському обласному кардіологічному диспансері та терапевтичних відділеннях Центральної міської клінічної лікарні.

Відповідно до типової навчальної програми 3 внутрішньої медицини для студентів медичного факультету вищих медичних навчальних закладів, на кафедрі розроблені методичні вказівки “Навчальна історія хвороби з внутрішньої медицини” для студентів 5 курсу лікувального факультету. Методичні вказівки включають рекомендації щодо оформлення паспортних даних (загальні відомості про пацієнта), скарг пацієнта з їх характеристикою, історії розвитку захворювання (anamnesis morbi), анамнезу за системами, історії життя хворого (anamnesis vitae), об’єктивного дослідження хворого (status praesens), попереднього діагнозу, лабораторних та інструментальних даних, консультацій фахівців, диференційного діагнозу, заключного (клінічного) діагнозу, плану лікування та його обгрунтування, щоденників спостереження, епікризу. Для правильного оформлення історії хвороби в кожному розділі методичних вказівок детально описані обов’язкова інформація, наведена методика розпитування хворого, збору анамнезу, фізикального обстеження.

Студентам необхідно вказати всі отримані при розпитуванні і обстеженні хворого дані, правильно сформулювати діагноз, інтерпретувати результати обстеження хворого, призначити додаткові методи обстеження, необхідні для встановлення діагнозу, обгрунтувати лікування і дози препаратів.

Оформлення історії хвороби сприяє інтеграції теоретичних знань і практичних навичок студентів і передбачає деталізоване виявлення скарг хворого, 3’ясування анамнезу, інтерпретацію даних лабораторного та інструментального обстеження, диференційного діагнозу, формулювання клінічного діагнозу, обгрунтоване призначення лікування та контроль його ефективності при динамічному спостереженні за хворим.

Робочий зошит студента, як форма самостійної роботи студента, створений для удосконалення організації самостійної роботи студента, більш ефективного використовування часу стимуляції розумової діяльності студентів; підвищення продуктивності навчання з предмета “Внутрішня медицина”. За допомогою створення так званого “портфоліо” досягнень студента надається можливість систематичної та безперервної самооцінки своїх знань, а також оптимізувати підготовку до аудиторних занять.
Для прикладу наводимо завдання із робочого зошита для студентів 5 курсу лікувального факультету за темою: “Набуті вади серця. Визначення. Вади мітрального, аортального, трикуспідального клапанів. Етіологія, механізми порушень геодинаміки. Класифікація. Комбіновані мітральні та аортальні вади. Клінічні прояви. Значення неінвазивних та інвазивних методів. Диференційний діагноз. Ускладнення. Показання до хірургічного лікування. Первинна та вторинна профілактика. Прогноз та працездатність”.

Завдання 4. Вирішіть ситуаційну задачу.

Хворому Ф. віком 54 роки проведено протезування аортального клапана (механічний протез Sant Jude № 25) у зв’ язку з дегенеративною-аортальною вадою серця з перевагою стенозу (градієнт тиску на AK-120 мм рт. ст.). Тривалий час у хворого спостерігається фібриляція передсердь з частотою шлуночкових скорочень 80-100 за хвилину. Отримує ривароксабан по 20 мг/день.

Об’єктивно: загальний стан задовільний. У легенях - везикулярне дихання. Тони серця ослаблені, прослуховується мелодія нормального функціонуючого металічного протеза St. Jude в аортальному положенні. Живіт м’який, печінка - нижній край пальпується по ребровій дузі.

ЕхоКГ: фракція викиду ЛШ - 44 \%, об’ємні та метричні показники в межах норми.

Ps. За 5 днів до операції був відмінений ривароксабан.

1. Який найбільш ймовірний діагноз у хворої Ф.?

2. Які діагностичні процедури необхідні для верифікації діагнозу?

3. Ваші рекомендації щодо подальшої тактики ведення хворого Ф.

Усі завдання у робочому зошиті виконуються самостійно студентом під час підготовки до заняття, викладення думки у текстових завданнях повинно бути лаконічне, логічне, послідовне. На початку заняття викладач перевіряє робочий зошит кожного студента, тим самим оцінюючи його готовність до заняття, рівень знань і умінь, набутих при самостійній підготовці до даної теми.

До кожної з навчальних тем студентові пропонується вирішити ряд завдань, які можуть бути декількох видів: ланцюгові, в яких одна правильна відповідь залежить від попередньої відповіді. Цьому допомагає створення графологічної структури теми, схем, графіків, діаграм, анкет, питань інтерв’ю, кросворди з відповідями до них, формування ін- 
формаційного блоку; тематичні, в яких присутня сукупність завдань будь-якої форми для контролю по одній темі і передбачає створення опорного конспекту, глосарію, узагальнюючої таблиці, матеріалу для презентації (з допомогою мультимедійної комп’ютерної програми Power Point); текстові, в яких представлено сукупність завдань відкритої форми для контролю знань навчального тексту (підготовка інформаційного повідомлення, написання реферату, есе, конспекту першоджерел, рецензії на текст, анотації); ситуаційні, які застосовуються для перевірки знань і умінь діяти в практичних ситуаціях і передбачає створення та вирішення тесту, еталонів відповіді до нього, створення та вирішення ситуаційних задач (кейсів), професійних алгоритмів та алгоритми диференційної діагностики.

При цьому до однієї теми пропонується п'ять завдань різних видів, які повинні виконуватись у тому порядку, в якому вони подані. Кожне завдання теми оцінюється в 0,1 бала, тому максимальна оцінка самостійної роботи підготовки за темою становить 0,5 бала.

Поряд з історією хвороби, робочим зошитом та тестовими завданнями однією з форм самостійної роботи є реферати. Практикується підготовка рефератів з тем, включених у навчальний план, але не освітлених на лекціях, що визначає необхідність самостійного пошуку літератури по заданій тематиці і засвоєння нового матеріалу. Також пропонуються теми, які розглядаються з метою повторення, або великі теми, з яких є достатньо додаткового матеріалу.

Загалом, реферат сприяє залученню студентів до системної роботи у бібліотеках з літературними, електронними джерелами, збагачує знання молоді та розвиває їхні аналітичні якості, ораторські вміння. Окрім цього реферат - це форма контролю самостійної наукової роботи студента, своєрідний письмовий звіт щодо досліджуваної проблеми 3 конкретної навчальної дисципліни. Якість реферату доцільно оцінювати за його захистом перед клінічною групою під час проведення дискусії чи рейтингового оцінювання знань із навчальної (наукової) проблеми, що розглядається. На основі реферату студенти під керівництвом викладача можуть підготувати тези, статтю в збірник наукових праць конференції з теми, що стосується певної проблеми.

Структура тексту реферату традиційна: вступ, основна частина, висновки, список використаних джерел. У вступі обгрунтовується актуальність теми, особливість обраного аспекту дослідження, його важливість для майбугньої практики. Потім характеризуються основні джерела, в яких найбільш повно й цілісно висвітлена тема (5-10 джерел).

Текст основної частини структурується за розділами (можлива подальша деталізація), що дає уявлення про основні змістові аспекти теми та показує авторські підходи до їх дослідження. Особисті міркування, узагальнення й висновки повинні будуватися на конкретному аналізі фактичного матеріалу або вивченні практичного досвіду роботи. Кожен розділ реферату завершується висновками. У підсумкових висновках доречно окреслити перспективи подальшого дослідження теми.

Тематичні завдання з самостійної роботи студентів 5 курсу з внутрішньої медицини складені згідно з 35 поточними темами занять і включають блок теоретичної інформації (визначення нозологічної форми, етіологія і патогенез, клінічна картина захворювання, принципи діагностики та диференційної діагностики, лікування) і тестові завдання 3 викладеного матеріалу. Блоки інформації студенти вивчають самостійно в спеціально відведений для цього час на заняттях (аудиторні робота) при методичному сприянні викладача, але без його безпосередньої участі.

У якості контролю самостійно отриманих знань та навичок використовуються вхідний і вихідний (підсумковий) тестовий контроль теоретичних знань, поточний і підсумковий контроль практичних навичок і умінь.

Висновки: 1. Навчальна історія хвороби є ефективною формою організації самостійної роботи студентів, що дозволяє оцінювати рівень теоретичної та практичної підготовки студентів.

2. Робочий зошит сприяє бліц-контролю засвоєння найбільш важливих констант у нормі і патології.

3. Тематичні завдання з тестами для самостійної роботи студентів $є$ ефективним видом організації самостійної роботи студентів при вивченні внутрішніх хвороб, що дозволяє скоротити позааудиторну навантаження студентів і ефективно контролювати самостійно отримані знання.

Отже, самостійна робота студентів $\epsilon$ важливою ланкою навчального процесу, дозволяє поглибити теоретичні знання, закріпити практичні навички, сприяє розвитку у студентів клінічного мислення, мотивації до навчання, вчить студентів культури спілкування з хворими, сприяє формуванню особистості лікаря. 


\section{Список літератури}

1. Колесников А. В. Организация и учебнометодическое обеспечение контроля самостоятельной работы / А. В. Колесников // Вышейшая школа. 2005. - № 5. - С. 66-69.

2. Лобанов А. П. Управляемая самостоятельная работа студентов в контексте инновационных технологий / А. П. Лобанов. - Мн. : РИВШ, 2005. -107 с.

3. Педагогические основы самостоятельной работы студентов : пособие для преподавателей и студентов / под общ. ред. О. Л. Жук. - Мн. : РИВШ, 2005. - 112 с.
4. Сергеенкова В. В. Управляемая самостоятельная работа студентов. Модульно-рейтинговая и рейтинговая системы / В. В. Сергеенкова. - Мн. : РИВШ, 2004. - 132 с.

5. Челышкова М. Б. Теория и практика конструирования педагогических тестов / М. Б. Челышкова. M., 2002. - 122 c. 